\title{
A Study of Vitamin D and Calcium Level in Beta Thalassemia Major in Duhok Province
}

\author{
Ghorbat Saleh Ali1,aa, Malika Kassem Najeeb $^{2, b}$, Amad M. Saleh Jubrail ${ }^{3, c}$, Zeliha Selamoglu, ${ }^{4, \text {,* }}$ \\ ${ }^{l}$ Faculty of Science, University of Duhok, Iraq \\ ${ }^{2}$ Faculty of Science, University of Duhok, Iraq \\ ${ }^{3}$ Faculty of Science University of Duhok, Iraq \\ ${ }^{4}$ Department of Medical Biology, Faculty of Medicine, Niğde Ömer Halisdemir University, 51240 Niğde, Turkey \\ *Corresponding author
}

\begin{tabular}{|c|c|}
\hline A R T I C L E I F O & A B S T R A C T \\
\hline $\begin{array}{l}\text { Keywords: } \\
\text { Blood serum } \\
\beta \text {-thalassemia major } \\
\text { Hemolytic anemia } \\
\text { Calcium } \\
\text { Vitamin D }\end{array}$ & $\begin{array}{l}\beta \text {-thalassemia major is severe hemolytic anemia which requires repeated blood transfusion and for } \\
\text { survival, which leading to iron overload. Serious complications due to iron over load are recognized } \\
\text { in the thalassemia patients. objectives Vitamin D and calcium are important factors for homeostasis } \\
\text { of calcium in this study. This study was conducted for a period of two year including from patients } \\
\text { with } \beta \text { - thalassemia major from Duhok Thalassemia Centre between } 2014-2015 \text {. Thirty eighth } \beta \text { - } \\
\text { thalassemia major patients and thirty eighth persons with age- matched as control group were } \\
\text { enrolled in the study. Serum concentration of } 25 \text { - hydroxy vitamin D and calcium were estimated by } \\
\text { enzyme linked fluorescent assay and colorimetric method, respectively. In patients, the level of } \\
\text { serum } 25-\text { hydroxy vitamin D was significantly lower } 11.11 \pm 4.36 \mathrm{ng} / \mathrm{mL} \text { compared with control } \\
\text { group ( } 14.03 \pm 5.96 \mathrm{ng} / \mathrm{mL}) \text {. Vitamin D deficiency is observed about } 94.73 \% \text { in patients. The mean } \\
\text { level of serum calcium in patients group is } 7.9 \pm 0.47 \mathrm{mg} / \mathrm{dL} \text { and } 8.98 \pm 0.77 \mathrm{mg} / \mathrm{dL} \text { in control group. } \\
\text { There was a statistically significant difference in serum calcium value between patients and control } \\
\text { group. } 44.73 \% \text { of patients have hypocalcaemia. This study demonstrated a high prevalence of } \\
\text { Vitamin D deficiency and low total serum calcium levels in thalassemia patients with a significantly } \\
\text { lower than healthy group. Hypocalcemia and vitamin D deficiency may be results from the negative } \\
\text { effect of the repeated blood transfusion and malnourishment. }\end{array}$ \\
\hline
\end{tabular}

\section{Introduction}

Beta-Thalassemia is a genetic abnormality which is an impaired or lack of the expression of the $\beta$-globin gene, causes $\alpha$ and $\beta$ globin chains impaired. Unbound globin in erythroid precursors in the bone marrow lead to their premature death, hence, to ineffective erythropoiesis, consequential in variable ranging from severe anemia to clinically asymptomatic individuals (Danjou et al., 2011).

$\beta$-Thalassemia major is a severe types of anemia that lifelong dependent to blood transfusion. Excess iron level in body and multiple transfusions put them at risk for iron overload which increases free radicals can cause oxidative stress through production of highly reactive hydroxyl $(\mathrm{OH})$ radicals, which lead to oxidative damage and dysfunction of several organs, such as, liver, heart and many glands like parathyroid and thyroid gland (Porter and Viprakasit, 2014; Sevindik, 2018; Sevindik et al., 2018; Sevindik,
2019). Appropriate chelating treatment prevents the iron accumulation in tissues and the adverse effects of iron overload (Cabantchik et al., 2005).

Variety of bone disorders are recognized $\beta$-thalassemia major patients such as bone and spinal deformation and delay in the growth and osteopenia or osteoporosis. Multifactorial attributed to bone disorder in the $\beta$ thalassemia patients. Expansion of the bone marrow, increased in the iron overload, hormonal deficiency, side effects of treatment and calcium/vitamin D deficiencies have negative effect on health of the bone (Mahachoklertwattana et al., 2003).

Naturally, vitamin D is a fat-soluble vitamin found in many foods. Also, it is created endogenously when skin is exposed to ultraviolet rays from sunlight under the two hydroxylations in the kidney and the liver tissue 
(Wintermeyer et al., 2016). Furthermore, Vitamin D is necessary for calcium metabolism (Casey et al., 2010; Schwetz et al., 2017).

Multiple studies have illuminated high rate of vitamin $\mathrm{D}$ deficiency in $\beta$ - thalassemia children and teenagers may contribute to variety of bone problems (Napoli et al., 2016; Fahim et al., 2013; Soliman et al., 2013). Deficiency of vitamin $\mathrm{D}$ in $\beta$ - thalassemia increases with older and age patients with thalassemia have considerably worse vitamin D status is compared with age-matched healthy control (Moulas et al., 1997). Normal level of the vitamin D is required for optimal reducing bone fracture in the $\beta$ thalassemia patients (Soliman et al., 2013). 25hydroxyvitamin $\mathrm{D}, 25(\mathrm{OH}) \mathrm{VD}$ is indicated the serum level in the body (Zittermann, 2003). The level of $25(\mathrm{OH})$ VD of $<20 \mathrm{ng} / \mathrm{ml}$ is evaluated to be VD deficiency (Holick, 2009).

Calcium is plentiful factor in human body that plays major functions in blood coagulation, mineralization of the bone, contraction of the muscle, and nerve excitability regulation, and finely controlled via both calcitonin and parathyroid hormone (Gallo et al., 2016). Hypocalcemia is a biochemical abnormality which may be asymptomatic in mild cases as life threatening metabolic disturbance or present as acute life aggressive that require rapid admission to hospital and correction. In contrast, when development of hypocalcaemia would progress slowly, patients can be surprisingly free of symptoms (Cooper and Gittoes, 2008). The aim of this study is to evaluate vitamin $\mathrm{D}$ and calcium level in the beta thalassemia major patients receiving regular blood transfusion, regularly on folic acid and chelating therapy in Duhok province.

\section{Materials and methods}

This brief study was performed from 1 st November to 30th September in Duhok between 2014 -2015, included thirty- eight $\beta$-thalassemia major patients, randomly selected to participate in study which aged 10-20 years in Duhok Thalassemia Centre. The protocol complied with all the relevant national regulations, institutional policies and in accordance with the Helsinki Declaration and was approved by the Thalassemia Centre in Duhok. Informed consent has been obtained from all individuals included in this study.

In the early age, severe anaemia had been diagnosed by initial $\mathrm{CBC}$ testing with peripheral smear and $\mathrm{Hb}$ electrophoresis. These patients were received monthly blood transfusion for maintaining haemoglobin above 9 $\mathrm{g} / \mathrm{dL}$. All patients were under daily supplementation with 1 $\mathrm{mg}$ of folic acid and iron chelating drug like the Deferasirox, (once-daily oral supplement) or Desferal, slow subcutaneous administration (over 8-12 hours for 57 days/week). Approximately, all of the patients have muscle and bone pain which interference with daily life activities and sleeping. The most common pain site is the lower back and can be especially annoying and intractable. Those patients with Splenectomy, other haemolytic anaemia and inadequate diet were excluded from the study. In addition, the healthy persons with comparable age which have the good nutritional without systemic disease were taken from school students as control group
Blood specimen was collected in plain tubes from antecubital vein of each individual in the morning, then centrifuged at $3000 \mathrm{rpm}$ for $10 \mathrm{~min}$. Serum was transmitted directly into other tube and frozen at $\left(-20^{\circ} \mathrm{C}\right)$ for later analyses. The level of 25-hydroxyvitamin D were performed by method of enzyme linked fluorescent assay (Biomerieux, Lyon, France). Serum vitamin D level less than $20 \mathrm{ng} / \mathrm{mL}$ indicates as VD deficiency. Calcium level investigation (reference range: $8.4-10.8 \mathrm{mg} / \mathrm{dL}$ ) was measured by colorimetric method, using a kit supplied by (Biolabo, Maizy, France).

Statistical analysis of the data was performed by using Excel and Graph Pad Prism 6. Results were expressed as means \pm standard deviation. Independent t-test was used for comparison of vitamin $\mathrm{D}$ and calcium between patients and control group. A $\mathrm{P} \leq 0.05$ was considered to be statistically significant.

\section{Results}

Table 1 shows the data of $\beta$-thalassemia major patients and control group which didn't observed any significant differences in ages.

Table 1 The parameters analysis of $\beta$-thalassemia major patients and control group

\begin{tabular}{l|lcl}
\hline \multicolumn{1}{c|}{ Values } & $\begin{array}{c}\beta \text {-thalassemia } \\
\text { major }\end{array}$ & $\begin{array}{c}\text { Control } \\
\text { Group }\end{array}$ & $\begin{array}{c}\mathrm{P} \\
\text { Value }\end{array}$ \\
\hline Age (year) & $14.08 \pm 3.02$ & $13.34 \pm 2.74$ & 0.27 \\
Vitamin D & $11.11 \pm 4.36$ & $14.03 \pm 5.96$ & 0.05 \\
\hline Calcium mg/dL & $7.9 \pm 0.47$ & $8.98 \pm 0.77$ & 0.001 \\
\hline \multicolumn{2}{l}{ Vitamin D: 25 -hydroxy vitamin D ng/mL }
\end{tabular}

Concentration level of vitamin D was $11.11 \pm 4.36$ $\mathrm{ng} / \mathrm{mL}$ in $\beta$-thalassemia major patients, whereas $14.03 \pm 5.96 \mathrm{ng} / \mathrm{mL}$ in normal subjects and the difference was statistically significant $(\mathrm{P}<0.05)$ between two groups. Results show vitamin D deficiently about $94.73 \%$ (36/38) of patients, while $78.94 \%$ (30/38) in control group, as shown in Figure 1.

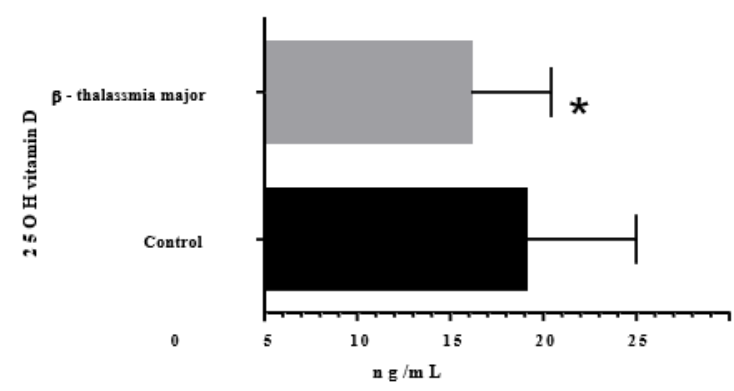

Figure 1 Mean \pm standard deviation of $25 \mathrm{OH}$ VD levels in $\beta$-thalassemia major patients and control group

Table 1 and Figure 2 show a statistically significant difference in the serum calcium levels between two groups ( $\mathrm{P}$ value $<0.001$ ). The mean level of serum calcium in patients group is $7.9 \pm 0.47 \mathrm{mg} / \mathrm{dl}$ and in control group is $8.98 \pm 0.77 \mathrm{mg} / \mathrm{dL}$. Hypocalcemia is a common finding in thalassemia patients. $44.73 \%(17 / 38)$ of those patients had serum calcium level $<8 \mathrm{mg} / \mathrm{dL}$. 


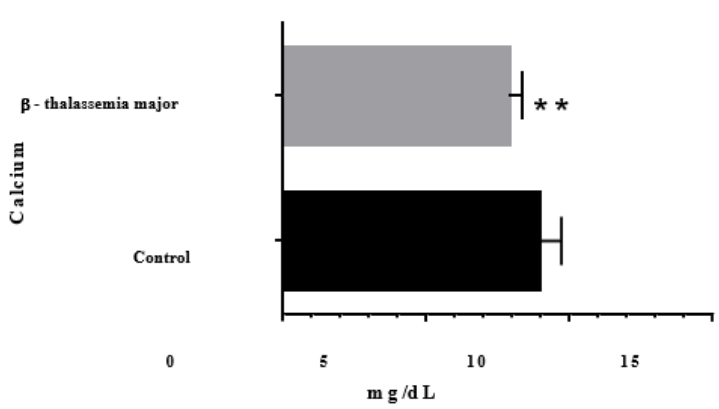

Figure 2 Comparison of the calcium level between $\beta$ thalassemia major and control group

\section{Discussion}

According to the results, the mean total serum vitamin $\mathrm{D}(11.11 \pm 4.36 \mathrm{ng} / \mathrm{mL})$ level was significantly lower in our patients than in control level $(14.03 \pm 5.96 \mathrm{ng} / \mathrm{mL})$; each $\mathrm{P}<0.005$. 94.73percent of patients had VD deficiency while in control group was 78.94 percent. Since, vitamin D is a prohormone has important role in calcium equilibrium, which increase intestinal calcium absorption (Holick, 2007). Without vitamin D, the body can be absorbing and select just about 60 percent of dietary phosphorus and 10 to 15 percent of dietary calcium. Sufficiency of VD promotes absorption of the phosphate and calcium approximately 30 to 40 percent and 80 percent respectively (Lips et al., 2016). In many studies are reported that reduction of the bone density in thalassemia was related to vitamin D impairment (Dandona et al., 1987; Napoli et al., 2006; Sultan et al., 2016). In the present study, in almost all cases (thalassemia patients and control persons) VD deficiency was experimental. VD deficiency is a common result for the Iraqi inhabitants, expectedly (Al-Horani et al., 2016).

Earlier Dandona, et al. (1987), from United Kingdom found that patients with thalassemia have considerably lower VD level than healthy persons. Napoli et al. (2006), reported the level of $25-\mathrm{OH}$ VD was $20.3+/-0.7 \mathrm{ng} / \mathrm{mL}$, while in age-matched normal persons was $25.2+/-1 \mathrm{ng} / \mathrm{mL}$. Additionally, other surveys showed that 100 percent of patients had VD deficiency (Soliman et al., 2008), Shamsiraz et al. (2003), reported about 37.2 percent whereas Vogiatzi et al (2009) mentioned about 12.8 percent of the patients had deficient and 82 percent insufficient. In United States of America, fourth three percent of patients had VD deficiency, which keep it up even with very little daily supply of VD (Fung et al., 2011). In the recent studies, the prevalence of 25-hydroxy vitamin D failure was shown 72.2 percent in thalassemia patients (Sultan et al., 2016). While Agrawal et al. (2016), determined that 98 percent in cases and in control group had defect of VD about 68 percent. The mean VD difference between cases and controls has been statistically reduced.

In patients with blood transfusion and overload of iron were observed impairment of the VD, otherwise the precise mechanism is unclear. In other way, the primary stage of the hydroxylation happens within the liver, this principle step may be interfering with overload of the iron and ultimately leading to defective hydroxylation instead of the endocrines dysfunction (Pirinççioğlu et al., 2011; Fahim et al., 2013; Ezzat et al., 2015). In addition, malabsorption and inadequate intake of vitamin D may be distinguished for these patients (Fung et al., 2012; Fahim et al., 2013).

In our research the mean of calcium level in thalassemic patients was lower than healthy persons, these results differ significantly $(\mathrm{P}<0.001)$ and frequency of hypocalcemia in thalassemia group was $44.73 \%$ (17/38). Al-Muhammadi (2014), reported the mean level of the serum calcium for males and females of $\beta$-thalassemia major cases were: $8.9 \pm 0.21 ; 9.3 \pm 0.312 \mathrm{mg} / \mathrm{dL}$, respectively and were significantly $(\mathrm{P}<0.05)$ lower than control males and females $(11.81 \pm 0.21 ; 12.0 \pm 0.112 \mathrm{mg} / \mathrm{dL}$, respectively.

Other study in Iraq indicated $21.7 \%$ from the patients had hypocalcemia with calcium level $1.61 \pm 0.23 \mathrm{mmol} / \mathrm{L}$ in the serum circulation (Al-Wtaify et al., 2009). On the other hand, Al-Samarrai et al. (2008), demonstrated the levels of calcium, phosphate, and sodium were within normal limits in the thalassemia patients. Frequency of hypocalcemia is reported to be $16.6 \%$ (Dresner et al., 2000), while Shah (2015), found $49 \%$ in the thalassemia patients. Hypocalcaemia may be correlated with inadequate of vitamin D synthesis and parathyroid impairment. In other hand, parathyroid hormone regulated normal levels of calcium and phosphorus in blood, the precipitation of iron in this gland leads to the insufficient production of parathyroid hormone (Barton, 2007). Furthermore, low parathyroid hormone level lead to excessive calcium loss in urine, one remodeling and decreased intestinal absorption of calcium which has negatively affected their bone metabolism (Cooper and Gittoes, 2008).

\section{Conclusion}

This study indicated that $94.73 \%$ of $\beta$-thalassemia patients have vitamin D deficiency, whereas hypocalcemia prevalence was $44.73 \%$ of these patients. Hypocalcemia and vitamin $\mathrm{D}$ deficiency may be results from the negative effect of the repeated blood transfusion and malnutrition. Future research should focus on the effect of dietary quality and nutritional status on health outcomes in thalassemia patients.

\section{References}

Agrawal A, Garg M, Singh J, Mathur P, Khan K. 2016. A comparative study of 25 hydroxy vitamin $\mathrm{D}$ levels in patients of thalassemia and healthy children. Pediatric Review: International Journal of Pediatric Research. 3(9): 652-656.

Al-Muhammadi MO. 2014. Changes in serum iron, total iron binding capacity, calcium and phosphorus concentrations in children with beta thalassemia major in Babylon Governorate. Kufa Med. Journal. 14(1): 253-261.

Al-Samarrai AH, Adaay MH, Al-Tikriti KA, Al-Anzy MM. 2008. Evaluation of some essential element levels in thalassemia major patients in Mosul district, Iraq. Saudi Medical Journal. 29(1): 94-97.

Al-Wtaify ASM and Al-Shujairi GSH. 2009. Prevalence of Diabetes and Hypocalcemia among Thalassemic Patients in Thalassemia Center in Babyl on Governorate. Medical Journal of Babylon. 6 (3-4): 672-679.

Barton JC. 2007. Chelation therapy for iron overload. Curr. Gastroenterol. ReP. 9: 74-82.

Cabantchik ZI, Breuer W, Zanninelli G, Cianciulli P. 2005. LPIlabile plasma iron in iron overload. Best Prat Res Clin Haematol. 18: 277-87. 
Casey CF, Slawson DC, Neal LR. 2010. Vitamin D Supplementation in Infants, Children, and Adolescents. Am Fam Physician. 81(6): 745-748.

Cooper MS and Gittoes NJ. 2008. Diagnosis and management of hypocalcaemia. BMJ. 336(7656): 1298-302.

Dandona P, Menon RK, Houlder S, Thomas M, Hoffbrand AV, Flynn DM. 1987. Serum 1,25dihydroxyvitamin D and osteocalcin concentrations in thalassemia major. Archives of disease in childhood. 62(5): 474-7

Danjou F, Anni F, Galanello R. 2011. Beta-thalassemia: from genotype to phenotype. Haematologica. 96(11): 1573-1575.

Dresner Pollack R, Rachmilewitz E, Blumenfeld A, Idelson M, Goldfarb AW. 2000. Bone mineral metabolism in adults with beta-thalassaemia major and intermedia. Br J Haematol. 111: 902-907.

Ezzat HM, John Wu J, McCartney H, Leitch HA. 2015. Vitamin D Insufficiency and Liver Iron Concentration in Transfusion Dependent Hemoglobinopathies in British Columbia. Open Journal of Hematology. 6-6 DOI: 10.13055/ojhmt_6_1_6.150608

Fahim FM, Saad K, Askar EA, Eldin EN, Thabet AF. 2013. Growth parameters and vitamin D status in children with thalassemia major in upper Egypt. Int J HematolOncol Stem Cell Res. 7(4): 10-14.

Fung E, Aguilar C, Micaily I, Haines D, Lal A. 2011. Treatment of vitamin $\mathrm{D}$ deficiency in transfusion-dependent thalassemia. Am J Hematol. 86: 871-3.

Fung EB1, Xu Y, Trachtenberg F, Odame I, Kwiatkowski JL, Neufeld EJ, Thompson AA, Boudreaux J, Quinn CT, Vichinsky EP. 2012. Inadequate dietary intake in patients with thalassemia. J Acad Nutr Diet. 112(7): 980-90.

Gallo L, Faniello MC, Canino G, Tripolino C, Gnasso A, Cuda G, Costanzo FS, Irace C. 2016. Serum Calcium Increase Correlates with Worsening of Lipid Profile: An Observational Study on a Large Cohort from South Italy. Medicine (Baltimore). 95(8): e2774

Al-Horani H, Abu Dayyih W, Mallah E, Hamad M, Mima M, Awad R, Arafat T. 2016. Nationality, gender, age, and body mass index influences on vitamin $\mathrm{D}$ concentration among elderly patients and young Iraqi and Jordanian in Jordan. Biochemistry Research International. ID 8920503, 8 pages

Holick MF. 2007. Vitamin D deficiency. New England Journal of Medicine. 357(3): 266- 81.

Holick MF. 2009. Vitamin D Status: Measurement, Interpretation and Clinical Application. Ann Epidemiol. 19(2): 73-78.

Lips P, Hosking D, Lippuner K, Norquist JM, Wehren L, Maalouf G, Ragi-Eis S, Chandler, J. 2006. The prevalence of vitamin D inadequacy amongst women with osteoporosis: An international epidemiological investigation. J Intern Med. 260: 245-54.

Mahachoklertwattana P, Sirikulchayanonta V, Chuansumrit A, Karnsombat P, Choubtum L, Sriphrapradang A, Domrongkitchaiporn S, Sirisriro R, Rajatanavin R. 2003. Bone histomorphometry in children and adolescents with $\beta$ thalassemia disease: iron- associated focal osteomalacia. Journal of Clinical Endocrinology and Metabolism. 88(8):966-3972.

Moulas A, Challa A, Chaliasos N, Lapatsanis PD. 1997. Vitamin D metabolites (25-hydroxyvitamin D, 24,25dihydroxyvitamin D and 1,25-dihydroxyvitamin D) and osteocalcinin B- thalassaemia. Acta Paediatr. 86: 594-599.
Napoli N, Carmina E, Bucchieri S, Sferrazza C, Rini GB, Di Fede G. 2006. Low serum levels of 25-hydroxy vitamin D in adults affected by thalassemia major or intermedia. Bone. 38(6): 888-92.

Pirinççioğlu AG, Akpolat V, Köksal O, Haspolat K, Söker M. 2011. Bone mineral density in children with beta-thalassemia major in Diyarbakir. Bone. 49(4): 819-823.

Porter J, Viprakasit V. 2014. Iron overload and chelation. In: Cappelini, Cohen A, Porter J, Taher A, Viprakasit V, eds. Guidelines for the management of transfusion dependent thalassemia (TDT). 3rd ed. Cyprus: TIF publication Pages 4274.

Schwetz V, Trummer C, Pandis M, Grübler MR, Verheyen N, Gaksch M, Zittermann A, März W, Aberer F, Lang A, Treiber G, Friedl C, Obermayer-Pietsch B, Pieber TR, Tomaschitz A, Pilz S. 2017. Effects of vitamin D supplementation on bone turnover markers: A randomized controlled trial. Nutrients. 9(5): article no. 432.

Sevindik M. 2018. Heavy metals content and the role of Lepiota cristata as antioxidant in oxidative stress. J Bacteriol Mycol Open Access. 6(4): 237-239.

Sevindik M. 2019. The novel biological tests on various extracts of Cerioporus varius. Fresenius Environmental Bulletin. 28(5): 3713-3717.

Sevindik M, Rasul A, Hussain G, Anwar H, Zahoor MK, Sarfraz I, Kamran KS, Akgul H, Akata I, Selamoglu Z. 2018. Determination of anti-oxidative, anti-microbial activity and heavy metal contents of Leucoagaricus leucothites. Pakistan journal of pharmaceutical sciences. 31(5 (Supplementary)): 2163-2168.

Shah S. 2015. Assessment of serum calcium and phosphorus levels among transfusion -dependent beta thalassemia major patients on chelation therapy. J Postgrad Med Inst. 29(3): 168-71.

Shamsiraz A, Bekheirnia MR, Kamgar M, Pourzahedgilani N, Bouzari N, Habibzadeh M, Hashemi R, Shamshirsaz AA, Aghakhani S, Homayoun H, Larijani B. 2003. Metabolic and endocrinological complications in beta- thalassaemia major: a multicenter study in Tehran. BMC Endocrine Disorder. 3:23-34.

Soliman A, Adel A, Wagdy M, Al Ali M, El Mulla N. 2008. Calcium homeostasis in 40 adolescentswith beta- thalassemia major: a case-control study of the effects of intramuscular injection ofa megadose of cholecalciferol. Pediatric Endocrinology Reviews. 6: 149-54.

Soliman A, De Sanctis V, Yassin M. 2013. Vitamin D Status in Thalassemia Major: An Update, Mediterr J Hematol Infect Dis. 5(1): e2013057

Sultan S, Irfan SM, Ahmed SI. 2016. Biochemical Markers of Bone Turnover in Patients with $\beta$-Thalassemia Major: A Single Center Study from Southern Pakistan. Adv Hematol. 2016:5437609. doi: 10.1155/2016/5437609.

Vogiatzi MG, Macklin EA, Trachtenberg FL, Fung EB, Cheung AM, Vichinsky E, Holm IA. 2009. Differences in the prevalence of growth, endocrine and vitamin D abnormalities among the various thalassaemia syndromes in North America. British Journal of Haematology. 146: 546-56.

Wintermeyer E, Ihle C, Ehnert S, Stöckle U, Ochs G, de Zwart P, Flesch I, Bahrs S, Nussler AK. 2016. Review Crucial Role of Vitamin D in the Musculoskeletal System. Nutrients. 8: 319.

Zittermann A. 2003. Vitamin D in preventive medicine: are weignoring the evidence? Br J Nutr. 89(5): 552-72. 